\title{
From Chinglish to New Chinglish — A Critical Exploration of Chinese ELF
}

\author{
Yiran Hou \\ University College London, London, UK
}

\begin{abstract}
Predominant status of English in politics, science, technology and intercultural communications leads to fierce debate over the so-called "ownership" of the English language. Considering the major agent in the spread and development of English around the world, increasing arguments have favoured the position of English as a lingua franca (ELF) shaped more by English's non-native speakers. This echoes growing advocacy in Chinese academia of legitimatising Chinese ELF and implementing it to the English education. This paper suggests the emergence of an imagined Chinese ELF community in response to the paradox under the Post-Multilingual context that individuals adopt and adapt English for intercultural communication while this may endanger local culture and identity. However, it argues that Chinese ELF is hard to be legitimatised officially and applied to teaching contexts due to its immanent self-contradiction and attitudes of the Chinese public - its aimed recipients - towards embracing and using it formally. Key point lies in the fact that under today's context of Anglo-hegemony, it is still native speakers who remain arbiters of the form of the English language spread and taught over the globe, essentially preventing Chinese ELF from being recognised.
\end{abstract}

Index Terms-Chinglish, ELF, language legitimacy

\section{INTRODUCTION}

Linguist David Crystal in his book (2004) defines English as a global language, since there had never been a language so widely spread and spoken by such a large population before. Both geographical-historical and sociocultural factors ensure the status of English at present in politics, science, technology and, most vitally, intercultural communications, therefore generating the concept of English as a lingua franca (ELF). It refers to communicative interactions during which "non-native speakers and all English varieties, native or non-native, are accepted in their own right rather than evaluated against a Native Speaker English benchmark" (Jenkins, Cogo, \& Dewey, 2011, p. 283).

Issues have thus arisen from the international use of the English language around the so-called "ownership" of English. From one perspective, so do they target on any other languages - linguistic descriptions have yet predominantly focused on English spoken and written by its native speakers (NSs); from the other perspective, supporters of ELF believe English should be shaped more by its non-native speakers (NNSs) than its NSs considering the number of both groups as well as the function of NNSs - it is them who are agents in the spread and development of English around the world (Brutt-Griffler, 2002). China, being a nation in the "expanding circle" of world Englishes where " a deep-rooted linguistic ideology and a rising nationalism are met with a desire for modernity" ( $\mathrm{Li}, 2016, \mathrm{p}$. 20), has bred an "imagined Chinese ELF community" to cope with various Post-Multilingualism challenges it faces. A growing number of domestic scholars have then advocated to legitimatise Chinese user's own English as a lingua franca (Chinese ELF) and implement it to the Chinese English education (e.g. Fang, 2017; Wang, 2012, 2013, 2015).

This paper, nevertheless, argues that despite the emergence of an imagined Chinese ELF community in response to the issues under present post-multilingual contexts, Chinese ELF is hard to legitimatise officially and implement to EFL teaching contexts due to its immanent self-contradiction and attitudes of the Chinese public — its aimed recipients towards embracing and using it formally; key point lies in the fact that under today's context of Anglo-hegemony, it is still NSs who remain arbiters of the form of the English language spread and taught over the globe, essentially preventing Chinese ELF from being recognised. To support my argument, first, I review the theoretical background of ELF consisting of its definition and related literature; the status of English in China is also briefly discussed. Second, I investigate the reasons contributing to the gathering of a Chinese ELF community in an ideological sense. Third, I critically analyse the limitations of Chinese ELF system from two perspectives, including its inherent self-contradiction and unobtainable recognition from the public. Then, I finalise this paper by concluding that considering current global contexts, though boasting increasing advocators, ELF may still be difficult to replace the position of ENL in China.

\section{THEORETICAL BACKGROUND}

\section{A. English as a Lingua Franca}

English as a lingua franca is regarded as "a contact language used only among non-mother tongue speakers" (Jenkins, 2006, p. 160) and heavily dependent on the specific situation of language use, being defined functionally by its use in intercultural communication rather than formally by its reference to native-speaker norms. This is to say, 
communicative efficiency is more vital than correctness. To accommodate to each other's cultural backgrounds and apply code-switching into other languages they know are common means adopted by ELF speakers. Despite its short history of only 20 years, ELF has undergone significant reconceptualisation and progression. In Conceptualising ELF (2017), Mauranen proposes the scientific foundation of how ELF, involving "contact between speakers with different 'similects' - the product, in turn, of contact between English and the particular L1 of the speaker in question", facilitates interactions - by establishing common frameworks of "prioritising enhanced explicitness with recourse to paraphrase, repetition and a degree of structural and lexical simplification" (ibid, p. 847); Hall et al.'s study (2017) on the cognitive processes underlying ELF interaction has further verified its justification.

Calls have thus been inspired for investigating the nature of ELF and its implications for L2 teaching and learning. With study focused on the characteristics of ELF interaction at the level of pragmatics (Cogo \& House, 2017), phonology (Gardiner \& Deterding, 2017), metaphor (Pitzl, 2009), lexico-grammar (Seidlhofer, 2004) and language norms (Hynninen \& Solin, 2017) to compile an ELF corpora (i.e. VOICE), the gradually accumulating research body, representing a deeper understanding towards ELF, leads to some ELF linguists' supports for a fundamental shift in language policy and English as a foreign language (EFL) teaching (McKay, 2002; Jenkins, 2004, 2006) that boasts ELF-awared teacher education (Sifakis \& Bayyurt, 2015) — from regarding ENL as the superior and standard model to recognising the position of ELF in English language teaching (ELT); namely, imparting features being crucial for international intelligibility based on Lingua Franca Core (LFC) to EFL learners.

\section{B. Community and ELF}

In accordance with Blommaert's (2010) view that globalisation has impacts on sociolinguistic issues and requires a perspective shift from language-in-place to language-in-motion, research into ELF at present goes beyond territoriality and generally probes into multilingual and multicultural practices where English plays a crucial role in interaction (e.g. Jenkins, 2015; Seidlhofer, 2011). Once being the cornerstone of sociolinguistic inquiry, nowadays links between language and geographical boundaries are criticised for its ignorance of pervasive trans-lingual and trans-cultural turns that symbolise the dynamics and adaptability of English in often-transient multicultural encounters, resonating the advocacy of ELF. Nevertheless, since it is scientifically-evident that there exists common ground between ELF users who share the same mother tongue (see Mauranen, 2012; Honna, 2012), while the notion of nation associated with the first language (L1) cannot be simply ignored, the trend of deterritorialisation of ELF that breaks the link between language and nation leaves an open question as to how to understand the connection between non-native English speakers who have shared L1 backgrounds and participate respective intercultural communication where ELF is relevant for them.

Therefore, Anderson's (2006) book on nationalism that highlights imaginedness and ideological dimension of community and membership proposes the concept of "imagined community". As for him, "communities are to be distinguished by the style in which they are imagined" (Anderson, 2006: 6); in other words, membership emerges in imagination and communities take shape in imagination. In "imagined communities", community members do not necessarily meet or even know each other but they conceive a core, "deep, horizontal comradeship" (ibid, p. 7). To put it more specifically, though it sets no limitation on physical space, an emotional attachment to the imagined affinity may gather members; besides, the plural form of this terminology infers both that there exists 'finite' boundaries — it is impossible to assume that all ELF speakers constitute a single and homogeneous global community (Ehrenreich, 2009; Mauranen, 2012) - and that this concept accepts independence and autonomy as an integral feature of communities. Based on this idea, Chinese ELF in this paper should not be defined in linguistic terms but in ideological terms - the formation of a Chinese ELF community is propelled by a spiritual core shared by Chinese ELF users.

\section{China: an "Expanding Circle" Nation in World Englishes}

As Rushdie comments in Imaginary Homelands (2012) that "the English languages ceased to be the sole possession of the English some time ago" (p. 14), no one today could claim absolute ownership of English, since the usage of this global language has long broken out of national and cultural boundaries. To better understand the patterns of English, Kachru in 1985 proposes a model of world Englishes consisting of three concentric circles — "inner", "outer" and "expanding" - each representing the types of spread, patterns of acquisition and functional domains in which English is used across cultures and languages. Nations in the inner circle are described as the traditional bases of English, namely, where it is the primary language. Countries of the outer circle are generally former UK colonial dependencies with people being English-as-a-second-langue (ESL) users instead of English-as-a-native-langue (ENL). While those situated in the expanding circles usually develop English named performance varieties, since they are learned as a foreign language and thus dependent upon inner circle countries in setting norms. China, belonging to expanding circles, is holding the largest population of EFL learners while it keeps fiercely increasing. According to Wei \& Su (2012), population of Chinese EFL learners has achieved approximately 400 million. The mushrooming of the English learning industry owing to the prevalence of English in the past several decades even stimulates some scholars to claim English to be a Chinese language (e.g. Jiang, 2003). Thus, it is necessary to explore English in China under today's contexts of Post-Multilingualism so as to investigate Chinese ELF into the future, offering a small window on the holistic development of ELF. 


\section{The Formation OF AN IMAGINED CHINESE ELF COMMUNITY}

As mentioned before, the conceptual paradox in considering Chinese speakers' ELF in association with China could be solved if Chinese ELF is defined in ideological terms rather than linguistically. To put it in other words, the grouping of Chinese ELF users is by no means a simple process of generalising their characterises of using ELF that yield to their mother tongue, facilitating communications in English between Chinese and non-Chinese; it is stimulated by a deeprooted comradeship. Under the framework of identity prototypes purposed by Gao (2014), gone are days when Chinese EFL users are faithful imitators "whose L2 use and cultural conduct were strictly modelled on the native speaker" (ibid, p. 60). Influenced by globalisation and postmodernism that bring Post-Multilingualism challenges, Chinese people endeavour to achieve a balance between protecting its national language and "recognising the (commercial) value of dialects, encouraging the learning of new (foreign) languages", as well as to "communicate and express its cultural values through a language that is traditionally associated with the Other or Others" ( $\mathrm{Li}, 2016, \mathrm{p} .19)$. This leads to the emergence of "an imagined Chinese ELF community" in Chinese ELF users' mental space (Wang, 2017, p. 7) with common perceptions - imagined affinity, imagined boundary, an emotional attachment to Chinese ethnicity (Wang, 2012) as well as the rebellion against authority, be it domestic or foreign — of their English in intercultural communication, breeding "legitimate speakers" and "playful creators" to satisfy public's needs of connecting to the global and promoting an updated ethnological image so as to not only reconstruct its self-identity, but also achieve others' recognition.

\section{A. Legitimate Speaker}

The legitimate speaker of English was originally the outcome of the postcolonial era, during which the colonial power of the UK was lingering dispersedly in various parts of the world, leading to the setback of linguistic hegemony. With neo-Marxist theory, feminist theories and critical theory at their backs, new concepts regarding the position of English, i.e. world English (Kachru, 1982) and ELF, have all contributed to the rise of legitimate speakers. "If 'faithful imitator' does not have an independent voice, the legitimate speaker is determined to articulate himself' (Gao, 2014, p. 64).

To investigate the appearance of legitimate speakers of Chinese ELF, it is thus necessary to recall ourselves of the history of Chinglish, which could be roughly divided into three strands (Wang, 2014). It begins with the early version of Pidgin English dated back to 1627 that functioned as the bridge between Chinese and foreigners who came to China for business, missionary service and colony rule (Eames, 1974). The second strand echoes a predominant pursuit of "correct" English in China (Wang, 2014), when the English education has been geared towards emphasising the authenticity and correctness of NSs' English (e.g. Jiang, 1995; Yip, 1995). While contextualising the growing power of China and increasing involvement of Chinese speakers in intercultural communication comes to the third strand with heated debate on the endonormativity of Chinese variety of English within the framework of ELF. It thus results in the stand-ups of legitimate speakers in (e.g. Fang, 2015; Wang, 2012, 2013, 2016) and out academia circles, both groups of which are mutually supported.

After a century of near silence, it is undeniable that China has made rapid growth in many areas since the Reform and Opening-up; while according to Li Wei, "China's emergence as a new politico-economic world power has been met with hostilities from both the United States and the neighbouring countries in East and Southeast Asia" (2016, p. 17). Given the temporary unshakeable position of English as the dominant language over the world due to economic and political reasons, the best way for Chinese people to express their sense of nationalism and national pride out of their emotional attachments to Chinese ethnicity or cultural root while simultaneously fight against the imposition of western power seems to be the adoption of Chinese ELF. In this term, China English (or Sinicized English) that is typically used by the Chinese authoritative English-language News Agency or publications could be regarded as an ideal evidence. Featuring Chinese characteristics while being comprehensible to NSs, it is usually adopted either for purely Sinocultural spread (i.e. exam-oriented education) or, under the disguise of it, for political purposes (i.e. harmonious society). Hu (2004) lists three reasons why China English should be promoted, since firstly it "retains a common core that renders it as intelligible to speakers of other varieties of English as Hiberno-English or Australian English" (p. 28); secondly, it is politically, economically and culturally more understandable to some other Asian countries, facilitating communication process; final one is the population size of China English speakers - he argues that a variety of English within China may very well dominate, due - if nothing else - to the sheer numbers of Chinese speakers and foreigners, new contacts with China (ibid). However, it ought to be reaffirmed that, for legitimate speakers of Chinese ELF users, the ultimate end is far more than simply being closely engaged to the global community and promoting Chinese ideologies in various fields which cannot be fulfilled with "authentic" English, but to "claim equal language standards and rights with NSs" (Gao, 2014, p. 63).

\section{B. Playful Creator}

New millennium brings a postmodern era of technological developments, increased globalisation, frequent international traveling and popularity of mass media that all promote world-wide linguistic and cultural flows, in which people live not "within a language but across languages" (Gao, 2014, p. 65) with "hybridity, ambivalences and fluidity are norms of daily life" (ibid, p. 66). Such a context borns the playful creators, who employ "unconventional 
hybridisation, fragmentation and juxtaposition of linguistic and cultural elements at surface level, to form distinct ways of self-expression" (ibid, p. 65). While it should be noticed that, to some degree, their critical playfulness overlaps the needs of legitimate speakers in their challenge of existing standards, while rather than fighting to be 'equal' users of the same language, they actually 'disinvent' the L2 and create their own L2 related 'creole' (Makoni \& Pennycook, 2005). This is to say, playful creators' typical way of interacting with the social environment is not serious negotiation or bitter fight, but expressing themselves in indirect and cynical means. New Chinglish is a typical product of the era today, which, according to Li Wei, is "a Translanguaging variety of English that has been reconstitute, re-appropriated, resemiotized, and re-inscribed by Chinese speakers of English via new media" (2016, p. 11-12). While it should be noted that in spite of its various categories, only those intelligible to NSs representing the phenomenon of Chinese ELF. Net Chinglish - new inventions of English words and expressions with Chinese characters to "express one's meanings and intentions, especially creator's social dissatisfaction" ( $\mathrm{Li}, 2016$, p. 15), i.e. freedamn: the combination of freedom and damn used to mock the freedom with Chinese characteristics — is a representative product of playful Chinese ELF creators. Superficially, the mass media gathers Chinese ELF users together in the virtual world for the entertaining purpose, creating trans-languaging words; while when probing much deeply, it is the mixing product of the rebellious spirits against either domestic or foreign authority, the desire of boasting a cool and modern element embedded in the Chinese characteristics and the affinity to an imagined global community that takes up part of psychological space of Chinese EFL speakers, contributing to an imagined Chinese EFL community. As Li Wei observes, what happens here is a paradoxical situation that "the private citizens are unhappy with what the state provides for them individually in their daily life", more specifically, the sense of inequality and depression, whereas they "yet ideologically united in national pride" (2016, p. 17). Besides, the Internet and mass media equip Chinese people with exterior ways to be exposed to the rest of the world, satisfying their inner aspiration for global community membership (Wang, 2012). Individuals are keen for connecting with outside so as to either convey their Chinese ethnological pride or present the new China's image of modernity and coolness under the new context; while in turn, make comparison to self-reflect and furthermore rebel against power imposed by the state authority.

To conclude, though, to a large extent, it could not be dichotomously separated from the national state, along with the political power embedded, the formation of an imagined Chinese ELF community in its members' psychological space is the corollary of responses, be they serious or playful, to challenges faced by China at this historical juncture where the increasing national pride and ambition to boast their own culture brought by the rise of China are coincident with individual's desire for freedom, power, and rights in China ( $\mathrm{Li}, 2016)$ - its appearance is by no means a coincidence, but an inevitable antidote.

\section{CHINESE ELF LEGITIMACY AND IMPLEMENTATION}

Despite the formation of an imagined Chinese ELF community ideologically, the endonormative orientation to Chinese speakers' English is suspended from being legitimated and implemented to EFL teaching context due to its immanent paradox, its relatively lower position compared to exonormativity in Chinese EFL speakers' mental space and, most crucially, the future of China in the world system.

\section{A. Immanent Self-contradiction}

ELF, acknowledged by most scholars, is "the term referring to a dynamic, situational natural linguistic phenomenon which embraces diverse socio-linguacultural identities (e.g., Jenkins et al., 2011; Seidlhofer, 2011; Mauranen, 2012)" (Ishikawa, 2015, p. 41). It should thus be concluded as "fluid, flexible, contingent, hybrid and deeply intercultural" (Jenkins, Cogo,\& Dewey, 2011, p. 284). Chinese ELF, equivalently, is an unstable non-system activity that facilitates linguistic communication rather than a concrete product, since what it focuses on is constantly altering and adjusted according to the context. From this perspective, its endornomative practices may inevitably "reifies and hypostatises 'ELF' as a seemingly stable form" (O'Regan, 2014, p. 533), containing a paradox in itself. Studies on ELF typically engage attempts to describe regular features of ELF, i.e. phonology, syntax, with Jenkins' (2000) LFC being characteristic of this "first wave" of ELF research. Scholars whose ultimate goal is "some kind of codification" (Jenkins, 2011, p. 287) comes up with two particularly well-known corpora of ELF — the Vienna-Oxford International Corpus of English (VOICE) and the ELF corpus of academic English (ELFA). While outdated though it claimed to be considering the long-lasted doubts, rebuttals and revisions, according to Jenkins, the codification of ELF, being the starting point of the whole study, is "an aim which, nevertheless, has not been dismissed out of hand" (ibid, p. 287). It should therefore be noticed that to trap those dynamic, fluid and constantly-updated linguistic phenomena into a rigid mode of generalisation, to a great extent, has already made ELF a field of self-contradiction.

Although part of the interest of ELF, from an orientation of features, transforming into current focus on "the processes underlying and determining the choice of features used in any given ELF interaction" (ibid, p. 287), investigating what makes communication in English successful in fluid and dynamic contexts (see Jenkins, Cogo \& Dewey, 2011). Driven by insights gained from corpora (see Seidlhofer, 2011), ELF research has identified a range of elements crucial for communicative success including accommodation (adapting to an interlocutor's speech style) and the use of various strategies to pre-empt or negotiate misunderstandings (Jenkins et al., 2011) that are deployed in each new interaction in order to make meaning and achieve communicative outcomes. From this perspective, ELF 
communication is purely a "context driven phenomenon" (Leung \& Lewkowitz, 2006), or as Canagarajah (2007) observes, "intersubjectively constructed in each specific context of interaction ... negotiated by each set of speakers for their purposes" (p. 926). However, be it focusing on phonological features or interactive strategies, it is yet a process of hypostatisation to describe a scene as an ELF interaction that deserves to be studied, as it "is about the way in which an abstraction 'ELF', in the discourse of the ELF movement, is made to appear already given, or 'real"' (O'Regan, 2014, p. 537). This is to say, despite their claims of moving forward, what ELF researchers study today, regardless its categorisation by region or function, is still "a hypostatised conception of ELF" (ibid, p. 538) that, in its essence, bridles a dynamic, situational, unstable non-system linguistic activity. Therefore, because of the problematic selfcontradiction, it is ideologically impossible to develop an endonormative form of Chinese ELF system that could be legitimated and implemented to English education in China.

\section{B. Unobtainable Recognition}

Graddol, in his book The Future of English (1997), introduces the notion of the Engco Model, which later has been adopted by the English Company (UK) Ltd as a way to examine the relative states of the world languages and making forecasts of the numbers of speakers of different languages based on demographic, human development and economic data in order to predict the global linguistic landscape of the 21st century. The global influence index score of English in 1995 is 100 while Chinese is only 22. Nevertheless, tremendous changes occurring in the past decade has modified Graddol's prediction from valuing ENL to pointing that Asia probably now holds the key to the long-term future of English as a global language, since while English is a major language, it only accounts for around $30 \%$ of the world Gross Domestic Product (GDP) (Davis, 2003). The rise of China, after a century of silence, should never be ignored or denied; however in the global context, overthrowing the position of ENL is never an easy task that could be fulfilled in the near future, or what could be anticipated simply depended on the analysis of GDP; it is deeply and complexly associated with capital exchange and commodification at a macro level.

Bourdieu (1986) divides capital into three basic types based on the field it functions - economic capital, cultural capital and social capital, whereas one form of capital, to a certain degree, could be converted to the other form. While in 1992, he further expounds the linguistic capital as the embodied cultural capital that produces "a profit of distinction on the occasion of each social exchange" (p. 55). As to him, the linguistic market, similar to others, is by no means a free market, for power relations within it predetermine the standards according to which linguistic capital is allocated, thus preserving the rule of the elite. In other words, linguistic capital perfectly mastered in the form of those who seize the power - in this sense, NSE - could be "transferred into other forms of capital like economic or social capital" (Smits \& Gündüz-Hoşgör, 2003, p. 830) and thus help the speakers of the legitimate language on their path to social success; in turn, the imperfect use of the dominant language, considering the political economy of capital and anglophone structural power, may create "symbolic barriers" against social and economic resources.

Compared to other nations that possess the depth of penetration of internationalisation of its population, China embraces a more complex soil for the development of ELF. Whereas in Europe a large percentage of research is conducted in English, in China almost every field of inquiry still has much of its fundamental research written in mandarin - even if later, key studies are then published in English. The rise of China combined with its deeply-rooted linguistic ideology might be another two-edged sword for the legitimacy of Chinese ELF. Different from those once having been colonies of either Britain or America, China has its own official language of mandarin that is closelyknotted to the cultural and economic power of the national states where it has always been the first language of the major population. This is to say, despite the Post-Multilingual context it is confronted with, the position of the Chinese language could never be swayed domestically - most Chinese people are still able to live without much involvement of the English language in their daily life while very few Chinese EFL learners actually transit to English daily users. For them, the acquisition of English, rather than a purely communicative tool, is more like a means to add up their linguistic capital, namely, their ability to use the right words, right grammar, register, tone, body language and so forth of, in this sense, inner-circle Englishes that is favourable by the social structure of the linguistic market where economic and political relations take a determining place. It is thus explicable that though an imagined Chinese ELF community exists for power negotiation, with legitimate speakers enthusiastically proposing English with Chinese characteristics as a legitimate variety of world English, all too often the majority of Chinese English learners or educators, subject to social structural constraints, show far less interest.

In the case of how a variety of English can be progressed to the status of recognition, Kachru in 1992 notes two factors - attitudes and teaching materials, both of which in China, nevertheless, offer the legitimacy of Chinese ELF a bleak prospect. With regards to the status quo of English pedagogical field that reflects clearly the superior position of ENL to ELF, NSs are more ambitiously recruited and offered more competitive packages, as they have long been believed to be automatically more competent at teaching their mother tongue. The unprecedented immense scale of ELT enterprise in China has been described as the most ambitious language-learning campaign in history (Hertling, 1996); its preference for NSs' English could be deemed as a strong evidence of Chinese costumers' needs of accumulating their linguistic capital in this fiercely-competitive global market, instead of simply being able to communicate with non-Chinese speakers. While apart from the English education, public's attitudes towards the use of Chinese ELF in the formal contexts, though varied, holistically are negative. A recent example is the sweeping criticism towards the English of a Chinese actress spoken in an advertisement video of Dior — wonderful grammar, heavy 
Chinese accent. The reason behind this stronger dissenting emotion is that the presence in this video, in public's opinions, represents China's national face and thus is expected to show "standard" English pronunciation - British or American. Probing more deeply is the fact that Chinese EFL learners are still driven by realistic principles of social comparison, and will prefer to target the most powerful varieties.

From Chinglish to New Chinglish, the process seemingly breeds a large number of ELF users actively creating English saturated with Chinese characteristics, while it should be noted that their creation is generally restricted to particular 'marginal' domains of language use (e.g. recreation, informal talk), leading to limited influences on the mainstream of social life. In terms of boosters of New Chinglish that largely involve younger generation whose social power is limited, albeit their practice could be extolled as heroic resistance against hegemony of linguistic standards, it remains to be further explored how "free" and "sincere" they are. Both legitimate speakers and playful righters of Chinese ELF, to a greater extent, appear to be powerful in L2 research, but may remain powerless and speechless in reality. To achieve the endornomativity of Chinese ELF, superficially, requires the acceptance and usage of Chinese EFL speakers, not simply in a playful mode in the virtual world, but more importantly, in actual world where language use is inseparably linked with power, capital exchange and social structure.

\section{CONCLUSION}

To conclude, this paper focuses on the complex situation of Chinese English. Echoing the paradox under the PostMultilingual context of how to balance the inevitable trend that individuals adopt and adapt English for intercultural communication while this phenomenon may endanger local Chinese culture and identity, it is obvious that people are still negotiating their identities in relation to the spread and use of English in China. All those contributing to an imagined Chinese community, the formation of which has been delved deeply into by analysing the emergence of legitimate speakers and playful creators of Chinese ELF users in this paper. Despite my favour that the number of Chinese ELF speakers would keep increasing considering public's multiple needs, I have critically argued that Chinese ELF is fundamentally difficult to be recognised and legitimised officially due to both internal and external reasons. A thorough ELF system that could be applied into English pedagogy inevitably requires the codification of the features of Chinese English, which, to a large degree, reifies and hypostatises 'ELF' as a seemingly stable form, thus contradicting the nature of this fluid and emergent linguistic phenomenon. Public's attitude is another obstacle for Chinese ELF to be use legitimately while the reason beneath this negative attitude is what fundamentally blocks the progressing course of Chinese ELF — capital.

In my opinion, English will continue to be used and function as an international language, whose influence will also continue to exert in China. The future of Chinese speakers' English is tied to the future of China; in turn, the endonormativity of Chinese speakers' English is tied to the development of China. However, considering temporary hardly-shakeable Anglo-dominant capital commodification and exchange in the global context, the legitimacy of Chinese ELF, along with its implementation to the English education in China, is more like a hopeful dream.

\section{REFERENCES}

[1] Anderson, B. (2006). Imagined communities, London; New York, VERSO.

[2] Bayyurt, Y., \& Sifakis, N. C. (2015). Developing an ELF-aware pedagogy: Insights from a self-education programme. New frontiers in teaching and learning English, pp. 55-76.

[3] Brutt-Griffler, J. (2002). World English: A study of its development (Vol. 34). Clevedon, UK: Multilingual Matters.

[4] Canagarajah, S. (2007). Lingua franca English, multilingual communities, and language acquisition. The modern language Journal, 91, pp. 923-939.

[5] Cogo, A., \& House, J. (2017). The pragmatics of ELF. The Routledge Handbook of English as a Lingua Franca. London/New York: Routledge, pp. 210-223.

[6] Crystal, D. (2004). The Cambridge encyclopedia of the English language. Cambridge: Cambridge University Press.

[7] Dewey, M., \& Patsko, L. (2017). ELF and teacher education. In J. Jenkins, W. Bakers and M. Dewey, eds, The Routledge Handbook of English as a Lingua Franca, pp. 441-455. London: Routledge.

[8] Eames, J. B. (1974). The English in China, London; New York; Curzon Press, Barnes \& Nobel Books.

[9] Ehrenreich, S. (2009). English as a Lingua Franca in multinational corporations - exploring business communities of practice. In A. Mauranen and E. Ranta, eds, English as a lingua franca: Studies and findings, pp. 126-151. Newcastle upon Tyne: Cambridge Scholars.

[10] Fang, F. G. (2017). English as a lingua franca: implications for pedagogy and assessment. TEFLIN Journal, 28(1). pp. 57-70.

[11] Gao, Y. (2014). Faithful imitator, legitimate speaker, playful creator and dialogical communicator: shift in English learners' identity prototypes. Language and Intercultural Communication, 14:1. pp. 59-75

[12] Gardiner, I. A., \& Deterding, D. (2017). Pronunciation and miscommunication in ELF interactions. The Routledge Handbook of English as a Lingua Franca, pp. 217-230.

[13] Graddol, D. (1997). The Future of English: A Guide to Forecasting the Popularity of the English Language in the 21st Century. London: British Council.

[14] Hall, C. J., Wicaksono, R., Liu, S., Qian, Y., \& Xu, X. (2017). Exploring teachers' ontologies of English: Monolithic conceptions of grammar in a group of Chinese teachers. International Journal of Applied Linguistics, 27(1). pp. 87-109.

[15] Honna, N. (2012). The pedagogical implications of English as a multicultural lingua franca. Journal of English as a Lingua Franca, 1(1). pp. 191-197 
[16] Hu, X. (2004). Why China English should stand alongside British, American, and the other 'World Englishes. English Today, 20(2).pp. 26-3

[17] Ishikawa, T. (2015). Academic rigour in criticising English as a Lingua Franca. Englishes in Practice, 2(2). pp. 39-48.

[18] Jenkins, J. (2000). The phonology of English as an International Language. Oxford: Oxford University Press.

[19] Jenkins, J. (2006) Current perspectives on teaching world Englishes and English as a lingua franca. TESOL Quarterly, 40.1. pp. $157-181$

[20] Jenkins, J. (2011). Accommodating (to) ELF in the international university. Journal of Pragmatics. 43. pp. 926-936.

[21] Jenkins, J., Cogo, A., \& Dewey, M. (2011). Review of developments in research into English as a lingua franca. Language teaching, 44(3). pp. 281-315.

[22] Jenkins, J. (2015). Repositioning English and multilingualism in English as a Lingua Franca. Englishes in Practice, 2(3). pp. 49-85.

[23] Jiang, Y. (1995). Chinglish and China English. English Today, 11. pp. 51-53.

[24] Kachru, B. B. (1982). The bilingual's linguistic repertoire. Issues in international bilingual education. pp. 25-52. Springer, Boston, MA.

[25] Kachru, B. (1985). Standards, codification and sociolinguistic realism: The English language in the outer circle. English in the World: Teaching and learning the language and literatures. pp. 11-30. Cambridge: Cambridge University Press.

[26] Kachru, B. B. (ed.). (1992). The Other Tongue: English across Cultures. Urbana and Chicago: University of Illinois Press.

[27] Kachru, B. B., Kachru, Y., \& Nelson, C. L. (Eds.). (2006). The handbook of world Englishes. Malden, MA: Blackwell.

[28] Ladegaard, H. J., \& Jenks, C. J. (2015). Language and intercultural communication in the workplace: Critical approaches to theory and practice. Language and Intercultural Communication, 15(1). pp. 1-12.

[29] Leung, C. and Lewkowicz, J. (2006). Expanding horizons and unresolved conundrums: Language testing and assessment. TESOL Quarterly, 40(1). pp. 211-234.

[30] Li, W. (2016). New Chinglish and the post-multilingualism challenge: Translanguaging ELF in China. Journal of English as a Lingua Franca, 5(1). pp. 1-25.

[31] Makoni, S., \& Pennycook, A. (2005). Disinventing and (re) constituting languages. Critical Inquiry in Language Studies: An International Journal, 2(3). pp. 137-156.

[32] Mauranen, A. (2012). Exploring ELF: Academic English shaped by non-native speakers, Cambridge, New York, Cambridge University Press.

[33] Mauranen, A. (2017). Conceptualising ELF. In J. Jenkins, W. Bakers and M. Dewey, eds, The Routledge Handbook of English as a Lingua Franca. pp. 27-44. London: Routledge.

[34] O'Regan, J. P. (2014). English as a lingua franca: An immanent critique. Applied Linguistics, 35(5). pp. 533-552.

[35] Pitzl, M. L. (2009). We should not wake up any dogs: idiom and metaphor in ELF. In A. Mauranen and E. Ranta, eds, English as a lingua franca: Studies and findings, pp. 298-312. Newcastle upon Tyne: Cambridge Scholars.

[36] Seidlhofer, B. (2001). Closing a conceptual gap: The case for a description of English as a lingua franca. International journal of applied linguistics, 11(2). pp. 133-158.

[37] Seidlhofer, B. (2004). Research perspectives on teaching English as a lingua franca. Annual review of applied linguistics, 24. pp. 209-239.

[38] Seidlhofer, B. (2011). Understanding English as a Lingua Franca, Oxford, Oxford University Press.

[39] Smits, J., \& Gündüz-Hoşgör, A. (2003). Linguistic capital: Language as a socio-economic resource among Kurdish and Arabic women in Turkey. Ethnic \& Racial Studies, 26(5). pp. 829-853.

[40] Wang, Y. (2012). Chinese speakers' perceptions of their English in intercultural communication (Doctoral dissertation, University of Southampton)

[41] Wang, Y. (2014). Chinese speakers' attitudes towards their own English: ELF or interlanguage. English Teaching in China, 5. pp. 7-12.

[42] Wang, Y. (2015). Chinese university students' ELF awareness: Impacts of language education in China. Englishes in Practice, 2(4). pp. 86-106

[43] Wang, Y. (2017). Chinese English as a lingua franca: an ideological inquiry. The Routledge Handbook of English as a Lingua Franca, pp. 151-164. London: Routledge.

[44] Wei, R. \& Su., J. (2012). The statistics of English in China. English Today, 28(3). pp. 10-14.

[45] Wenger, E. (1998). Communities of practice: Learning, meaning, and identity, Cambridge, Cambridge University Press.

[46] Yip, V. (1995). Interlanguage and learnability: From Chinese to English, Amsterdam, John Benjamins.

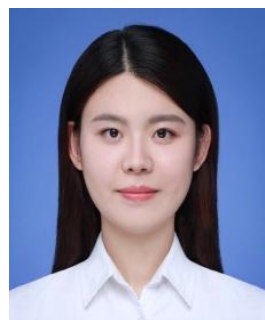

Yiran Hou obtained her B.A. degree in English Language and Literature from China Pharmaceutical University, Jiangsu, China in 2018 and M.A. degree in Applied Linguistics from University College London, London, UK in 2019. Her research interests are focused on the areas of digital communication, English as a lingua franca and second language writing.

She has taught English as a foreign language (EFL) both at the middle school and tertiary levels in her home country, China. She is currently working as a Lecturer teaching two undergraduate level courses: Comprehensive English and English Listening and Speaking at Jiangsu Maritime Institute, Jiangsu, China. 